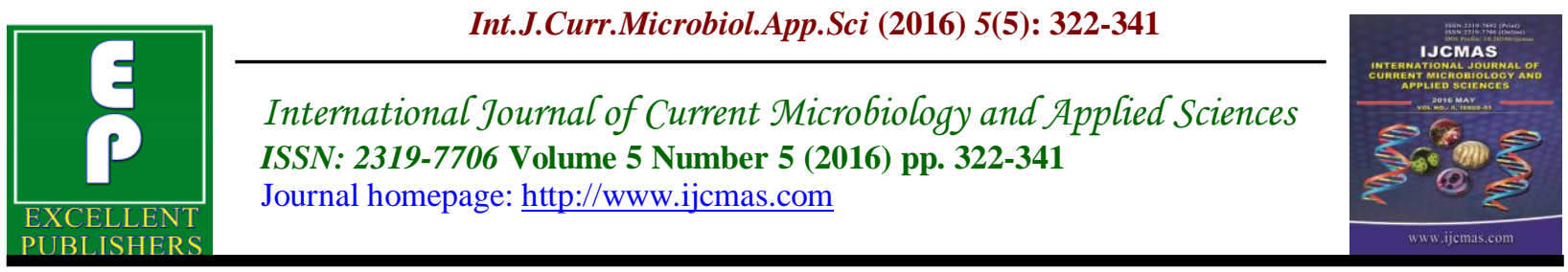

Original Research Article

http://dx.doi.org/10.20546/ijcmas.2016.505.034

\title{
Effect of Organophosphate Insecticide, Dimethoate on Physiology of Common carp, Catla catla (Hamilton) and Labeo rohita
}

\author{
Mohammad Illiyas Hussain ${ }^{1}$, Baidyanath Kumar ${ }^{2 *}$ and Mumtaz Ahmad ${ }^{3}$ \\ ${ }^{1}$ Research Scholar, Department of Zoology, Oriental College, Patna, India \\ ${ }^{2}$ Visiting Professor, Department of Biotechnology, College of Commerce, Patna, India \\ ${ }^{3}$ Head, Department of Zoology, Oriental College, Patna, India \\ *Corresponding author
}

\section{Keywords \\ LC50, \\ Dimethoate, \\ Catla catla, \\ Labeo rohita \\ Toxicity, Serum composition, Isoenzymes.}

\begin{tabular}{l}
\hline Article Info \\
\hline Accepted: \\
15 April 2016 \\
Available Online: \\
10 May 2016
\end{tabular}

A B S T R A C T

In the present investigation the effects of Dimethoate insecticide on survival chance (acute toxicity), behavioral response and blood biochemical and haematological parameters and the expression of isoenzymes in Catla catla (Hamilton) and Labeo rohita (Hamilton) after exposure to sublethal concentrations of Dimethoate was studied. It is evident that no mortality of Catla catla and Labeo rohita was recorded at $20.5 \mathrm{mg} / \mathrm{l}$ Dimethoate up to $24 \mathrm{hrs}$. of exposure. At concentrations of 23.0, 23.5 and $24.0 \mathrm{mg} / \mathrm{l}$ of Dimethoate $100 \%$ mortality of Catla catla was recorded at three different concentration of Dimethoate viz., $23.0 \mathrm{mg} / 1,23.5 \mathrm{mg} / \mathrm{l}$ and $24.0 \mathrm{mg} / \mathrm{l}$ in $96 \mathrm{hrs}$. of exposure. The LC50 values of Dimethoate at various exposure times were $21.0 \mathrm{mg} / \mathrm{l}$ for about $84 \mathrm{hrs} ; 21.5 \mathrm{mg} / \mathrm{l}$ for $72 \mathrm{hrs} ; 22.0 \mathrm{mg} / \mathrm{l}$ for about $60 \mathrm{hrs} ; 22.5 \mathrm{mg} / \mathrm{l}$ for $48 \mathrm{hrs}$; $23.0 \mathrm{mg} / \mathrm{l}$ for $48 \mathrm{hrs}$; and $23.5 \mathrm{mg} / \mathrm{l}$ for $24 \mathrm{hrs}$. The percentage mortality of Catla catla increased with increased concentration of Dimethoate and with decreased exposure time. Similarly at concentrations of 23.0, 23.5 and $24.5 \mathrm{mg} / \mathrm{l}$ of Dimethoate $100 \%$ of mortality of Labeo rohita was recorded. Catla catla and Labeo rohita showed behavioral alterations against Dimethoate intoxication. Uncoordinated movements, erratic swimming, convulsions, excess mucus secretion, decreased opercular movements, loss of balance, drowning and change in body pigmentation, muscle fasciculation. Moribund lethargy, refusal of feeding, respiratory distress became more apparent with increase in duration of exposure at all test concentration of Dimethoate. The glycogen content, total proteins and total lipids decreased in the blood of Catla catla and Labeo rohita under the toxicity of Dimethoate whereas the levels of total free sugars and total free amino acids increased. Dimethoate caused reduction in total proteins in the blood of both Catla catla and Labeo rohita. The acute exposure to Dimethoate resulted in a significant decrease in count of developmental forms of myeloid sequence and the segmented neutrophilic granulocytes in the experimental group. Catla catla and Labeo rohita exposed to acute effects of the Dimethoate insecticide showed significantly $(\mathrm{P}<0.01)$ decreased concentration of alkaline phosphatase and significantly $(\mathrm{P}<0.01)$ increased concentration of ammonia, aspartate aminotransferase, lactate dehydrogenase,creatine kinase and lactate in blood plasma. The main biochemical blood profile response of Catla catla and Labeo rohita to the acute effect of $23.5 \mathrm{mg} / \mathrm{l}$ of Dimethoate was a significantly $(\mathrm{P}<0.01)$ decreased concentration of alkaline phosphatase and significantly $(\mathrm{P}<0.01)$ increased concentration of NH3. LDH. AST. CK and LACT in blood plasma. 


\section{Introduction}

Water pollution caused by pesticides has become a serious problem. Contaminants of varied nature exist in surface waters which include multiple chemical compounds and different products of industrial and agricultural revolution. The insecticides constitute major pollutants which contribute to the environmental problems. Application of insecticides has contributed greatly in enhancing crop yields and also for the control of insect- borne diseases. Excessive use of broad- spectrum or non- selective insecticides damage the ecosystem, sometimes irreversibly, contaminates soil surface and ground water as well as food webs and thus compromises the health and well being of the inhabitants of the aquatic and terrestrial ecosystems.

Contamination of water by pesticides, either directly or indirectly, can lead to fish kills, reduced fish productivity, or elevated concentrations of undesirable chemicals in edible fish tissue which can affect the health of humans consuming these fish. Residual amounts of pesticides and their metabolites have been found in drinking water and foods, increasing concern for the possible threats to human health posed by exposure to these chemicals. Contamination of surface waters has been well documented worldwide and constitutes a major issue at local, regional, national, and global levels (Cerejeira et al., 2003; Spalding et al., 2003).

There are many pathways by which insecticides leave their sites of application and distribute throughout the environment and enter the aquatic ecosystem. The major route of insecticides to aquatic ecosystems is through rainfall, runoff and atmospheric deposition. Another source of water contamination by insecticides is from municipal and industrial discharges. Most insecticides ultimately find their way into rivers, lakes and ponds (Tarahi Tabrizi, 2001; Honarpajouh, 2003; Bagheri, 2007; Shayeghi et at., 2007; Vryzas et al., 2009; Werimo et al., 2009; Arjmandi et al., 2010) and have been found to be highly toxic to non- target organisms that inhabit natural environments close to agricultural fields. The contamination of surface waters by insecticides causes adverse effects on growth, survival and reproduction of aquatic animals. The increase of mortality among the fish in various water bodies has drawn attention of researcher to the problems caused by insecticides runoff associated with intense agricultural practices. Different concentrations of insecticides are present in water bodies and found to be toxic to aquatic organisms especially fish (Talebi, 1998; Uner et al., 2006; Banaee et al., 2008). Fishes are highly sensitive to the environmental contamination of water. Hence insecticides, serious pollutants may significantly damage certain physiological and biochemical processes when they enter into the organs and tissues of fish (John, 2007; Banaee et al., 2011). It has been found that different kinds of insecticides can cause serious impairment to physiological and health status of fishes (Begum, 2004; Monteiro et al., 2006; Siang et al., 2007; Banaee et al., 2009). Since fishes are important sources of proteins and lipids for humans and domestic animals, so health of fishes is important for human beings.

Among different classes of insecticides, organophosphates are more frequently used because of their high insecticidal property, low mammalian toxicity, less persistence and rapid biodegradability in the environment. Dimethoate [IUPAC Name- O, O- dimethyle S- (N methyl carbamoylmethyl) phosphoro- dithioate] is an organophosphate available in the market 
by the trade name of ROGER. It is a broad spectrum systemic insecticide active against acaridae, aphididae, aleyrodidae, coccodidea, coleopteran, collembolan, dipteral, Lepidoptera, pseudococcidae and thynoptera in cotton, cereals, fruits, vegetables, tea, coffee, tobacco and pastures (Aysal et al., 2004). Dimethoate is an inhibitor of enzyme cholinesterase and causes accumulation of acetylcholine in nerve tissue (synapses of the central and peripheral nervous system) and effectors organs with the principal site of action being the peripheral nervous system (Cope, 2004). The accumulation of acetylcholine results in a prolonged stimulation of the cholinergic receptors downstream leading to intense activation of autonomic nervous system, which depending upon the severity of acetyl cholinesterase inhibition results in tremors, convulsion, respiratory arrest and death (Breckenridge and Stevens, 2008).

Lactate dehydrogenase (EC 3.1.1.27) is one of the chief enzyme of carbohydrate metabolism which catalyses the oxidation of lactate and reduction of pyruvate during anaerobic glycolysis. It is a tetrameric molecule consists of two separate loci which code for A and B subunits of this enzyme. The A and B subunits indiscriminately associate and form five tetrameric isozymes (A4, A3B1, A2B2, A1B3 and B4) (Fujio and Kaneko, 1980). Isozymes are multiple forms of a single enzyme, which often have different isoelectric points and therefore can be separated by electrophoresis. Electrophoretic studies were done extensively on the different tissues of various animals from which it reveals that the enzyme exhibit in multi molecular forms and functions (Markert and Moller, 1959). LDH electrophoretic patterns could help in investigating and to locating the pesticide stress. Stress reflects on respiratory metabolism as LDH is a key enzyme in carbohydrate metabolism and occurs virtually in all tissues. It is indicative of variation in tissue functioning as a consequence of presence, increase or decrease in the concentration of the toxicant (Jyothirmayee et al. 2005).

The present investigation depicts the effects of Dimethoate insecticide on survival chance (acute toxicity), behavioral response and blood biochemical and haematological parameters and to evaluate the expression of Isoenzymes in Catla catla (Hamilton) and Labeo rohita (Hamilton) after exposure to sub lethal concentrations of Dimethoate.

\section{Materials and Methods}

Live specimens of freshwater carp, Catla catla (Hamilton) and Labeo rohita (Hamilton) were collected from local pond of Patna city with the help of fisherman and carefully packaged into aerated polythene bags filled with tap water. In the laboratory fishes were disinfected by treatment of $0.05 \%$ potassium per magnate and transferred into large plastic tanks containing 500liters of dechlorinated tap water for acclimatization for 15 days. During acclimatization water of the tank was changed daily and fish were fed dried shrimp twice a day.

The experiment was conducted under natural photoperiod and temperature in the months of September - October, 2015. The physicochemical characteristics of experimental water used were as follows: $\mathrm{pH} \quad 7.40 \pm \quad 0.2 ; \quad$ dissolved oxygen $8.35 \pm 0.15 \mathrm{mg} / \mathrm{l}$; temperature $20.00 \pm 20 \mathrm{C}$; free carbon dioxide $6.5 \pm 0.5 \mathrm{mg} / \mathrm{l}$; total hardness as calcium carbonate $135 \pm 5.25 \mathrm{mg} / \mathrm{l}$; and electrical conductivity $285.36 \pm 60.45$ $\mu \mathrm{mho} / \mathrm{cm}$.

The acclimatized Catla catla of length $7.5 \pm 1.5 \mathrm{~cm}$ and weight $12.0 \pm 3 \mathrm{gm}$ and Labeo 
rohita of length $6.5 \pm 1.5 \mathrm{~cm}$ and weigh $10.5 \mathrm{gm}$ were sorted and starved for $24 \mathrm{hr}$. before starting the experiment. Stock solution of Dimethoate (EC30\%, Rallis India Ltd) was prepared in absolute alcohol. Five replicates, each containing ten fish were subjected to Dimethoate at eight different concentrations of 20.5, 21.0, 21.5, 22.0, 23.0, 23.5, and 24.mg/l. Control groups, each having ten fish kept in tap water containing $0.4 \mathrm{ml} / 1$ acetone was run concurrently. All experiments were carried out in cylindrical glass aquaria containing 30 liters of test solution. All solutions (control and test) were renewed daily and dead fishes were immediately removed.

The behavioral changes and mortality of the fish were recorded at four different exposure periods viz, 24, 48, 72 and $96 \mathrm{hr}$. The data on the mortality rate of fish was recorded. The dead fish were removed immediately. The toxic tests were conducted to choose the mortality range from ten percent to ninety percent for $24 \mathrm{hrs}$ in static tests. The concentration that produced fifty percent mortality in test species noted. LC50 values were calculated by Finney's Probit analysis (1971).

The blood from the fishes were collected and subjected to biochemical analysis, such as total free amino acids (Yemm and Cocking, 1957), total proteins (Gornall et al., 1949), total free sugars (Roe, 1955), glycogen (Kemp and Kits, 1975) and total lipids (Barnes and Black Stock, 1973).

\section{Biochemical and Haematological Profile following Dimethoate Exposure}

Examinations were performed after $96 \mathrm{~h}$ exposure period with Dimethoate at an exposure level of $96 \mathrm{~h}$ LC50 (21.0mg/l). Catla catla and Labeo rohita in the control group were monitored concurrently. The test was performed in sixteen 300 liter tanks. Each tank contained 20 Catla catla and 20 Labeo rohita i.e. six tanks with $96 \mathrm{hLC} 50$ of Dimethoate, and one control tank with Catla catla and one control tank with Labeo rohita. Tanks for all treated fish and controls were replicated, Presence of the tested substance (above $80 \%$ of the nominal concentration) was ensured through a $12 \mathrm{~h}$ exchange of the water bath. Determination of Dimethoate concentration in water was measured using gas chromatography (Mekebri et al., 2008). Forty-eight experimental (8 fish from each pesticide duplicated) Catla catla or Labeo rohita and sixteen control Catla catla or Labeo rohita were selected at random and used for haematological and biochemical examination at the end of the $96 \mathrm{~h}$ exposure. Blood was sampled from the vena caudalis, using an $18 \mathrm{G} \times 1$ 1/2 in syringe. Fish were not anaesthetized prior to blood sampling, as they were calm due to low water temperature and there was no danger of tissue trauma or handling stress. Heparin was used as an anticoagulant (Heparin inj., Leciva, Czech Republic) at a concentration of 40 I.U. heparin sodium salt in $1 \mathrm{ml}$ blood. The indices used to evaluate the haematological profile included erythrocyte count (RBC), haemoglobin concentration $(\mathrm{Hb})$, haematocrit $(\mathrm{PCV})$, mean erythrocyte volume (MCV), mean colour concentration (MCHC), erythrocyte haemoglobin ( $\mathrm{MCH})$, leukocyte count (Leuko), and the differential leukocyte count (Leukogram). The procedures were based on unified methods for haematological examination of fish (Svobodova et al., 1991). Blood was sampled by v. caudalis as mentioned above. Plasma was obtained by centrifuging blood samples in a cooled centrifuge $\left(4{ }^{\circ} \mathrm{C}\right.$, $837 \times g$ ). Plasma samples were held at -80 0C until analysis. Biochemical indices included glucose (GLU), total proteins (TP), albumins (ALB), total globulins (GLOB), 
ammonia (NH3), tricylglycerols (TAG), aspartate aminotransferase (AST), alanine aminotransferase (ALT), lactate dehydrogenase (LDH), gama-glutamyl-transferase (GGT), creatine kinase (CK), lactate (LACT), alkaline phosphatase (ALP), calcium $(\mathrm{Ca} 2+)$, magnesium $(\mathrm{Mg})$, and inorganic phosphate (PHOS). For the biochemical analysis of blood plasma, the VETTEST 8008 analyzer (IDEXX Laboratories Inc., Maine, USA) was used

\section{Results and Discussion}

The LC50 values of Dimethoate for 24, 48, 72 and 96 hours of exposure have been presented in Table-1 and 2. From the results it is evident that no mortality of Catla catla and Labeo rohita was recorded at $20.5 \mathrm{mg} / 1$ Dimethoate up to $24 \mathrm{hrs}$. of exposure. At concentrations of 23.0, 23.5 and $24.0 \mathrm{mg} / 1$ of Dimethoate $100 \%$ mortality of Catla catla was recorded at three different concentrations of Dimethoate viz., $23.0 \mathrm{mg} / \mathrm{l}$, $23.5 \mathrm{mg} / \mathrm{l}$ and $24.0 \mathrm{mg} / \mathrm{l}$ in $96 \mathrm{hrs}$. of exposure. The LC50 values of Dimethoate at various exposure times were $21.0 \mathrm{mg} / 1$ for about $84 \mathrm{hrs} ; 21.5 \mathrm{mg} / 1$ for $72 \mathrm{hrs} ; 22.0 \mathrm{mg} / 1$ for about 60hrs; $22.5 \mathrm{mg} / \mathrm{l}$ for $48 \mathrm{hrs}$; $23.0 \mathrm{mg} / \mathrm{l}$ for $48 \mathrm{hrs}$; and $23.5 \mathrm{mg} / \mathrm{l}$ for $24 \mathrm{hrs}$. The percentage mortality of Catla catla increased with increased concentration of Dimethoate and with decreased exposure time. Similarly at concentrations of 23.0, 23.5 and $24.5 \mathrm{mg} / \mathrm{l}$ of Dimethoate $100 \%$ of mortality of Labeo rohita was recorded. The present findings gain support from the work of Anoop et al., (2010) who also recorded LC50 values of Dimethoate in Heteropeunistis fossilis. Shukla (1995) reported the LC50 value of Dimethoate for Colisa fasciatus as $13.0 \mathrm{mg} / \mathrm{l}$ for $24 \mathrm{hrs}$, $11.4 \mathrm{mg} / \mathrm{l}$ for $48 \mathrm{hrs}, 10.0 \mathrm{mg} / \mathrm{l}$ for $72 \mathrm{hrs}$ and $9.3 \mathrm{mg} / \mathrm{l}$ for $96 \mathrm{hrs}$. Vittozzi and Angelis (1991) reported $0.78 \mathrm{mg} / \mathrm{l}$ and $0.79 \mathrm{mg} / \mathrm{l}$ as 96 hrs LC50 values of Dimethoate for blue gill and trouts respectively. The 96hrs LC50 value for Dimethoate for Lebister reticulates has been reported as 19mg/l (Gupta et al., 1984). The 96hrs LC50 value for Dimethoate to the fish Cyprinus carpio has been reported as $26.11 \mathrm{mg} / 1$ (De $\mathrm{Mel}$ and Pathiratne, 2005). The median lethal concentration (LC50) of Dimethoate to fresh water food fish, Clarius batrachus has been recorded as 65ppm by Begum (1993). The acute toxicity values of Dimethoate (96hrsLC50) for fish species found in Canada ranged from $6 \mathrm{mg} / \mathrm{l}$ for blue gill (Lepomes macrochirus) to $22.4 \mathrm{mg} / 1$ for carp (Cyprinus carpio, 7 days LC50) (C.C.M.E, 1999).Sweilum (2006) reported 40mg/l concentration of Dimethoate as LC50 for 96hrs exposure to fish Nile tilapia (Oreochromis niloticus). In the present investigation the LC50 values of Dimethoate to Catla catla were recorded as $21.5 \mathrm{mg} / 1$ for $72 \mathrm{hrs} ; 22.0 \mathrm{mg} / 1$ for $60 \mathrm{hrs} ; 22.5 \mathrm{mg} / 1$ and $22.0 \mathrm{mg} / \mathrm{l}$ for $48 \mathrm{hrs}$ and $23.5 \mathrm{mg} / \mathrm{l}$ and $24.0 \mathrm{mg} / 1$ for $24 \mathrm{hrs}$ of exposure. The LC50 values of Dimethoate to Labeo rohita were recorded as $20.5 \mathrm{mg} / 1$ for $96 \mathrm{~h} ; 21.0 \mathrm{mg} / 1$ for $72 \mathrm{~h} ; 21.5,22.0,22.5$ for $48 \mathrm{~h}$ and $23.0 \mathrm{mg} / \mathrm{l}$, 23.5 and 24.0 for $24 \mathrm{~h}$. So it is difficult to compare the toxicity of Dimethoate insecticides to Catla catla and Labeo rohita because the toxicity is also influenced by several factors like temperature, hardness, $\mathrm{pH}$ and dissolved oxygen content of the test water. The result is also in accordance of Schimmel et al., (1976).

The interrelationship between ambient temperature and susceptibility of fish to toxicants appear to be a common feature. A wide range of insecticides have been found to increase the toxicity at higher temperature (Macek and Cope, 1969; MuirheadThomson, 1971).

The mechanism involved in the increase of susceptibility of fish to toxicants with rise in 
temperature is not well understood (Singh and Narain, 1971), though effect on general metabolism and respiration rate could largely be involved (Mackek et al., 1969; Wedemeyer et al., 1976; Gordon and McLeay, 1977). Rise in water temperature reduces the solubility of oxygen in water which could affect fish physiology. It could increase the metabolic rate (oxygen demand) of fish (Davis, 1975), limiting the affectivity of blood oxygen and hemoglobin affinity for oxygen (Bohr effect), thus resulting in low dissolved oxygen levels and greater accumulation of waste products and lowering the resistance of fish to stress. Reduced solubility of oxygen in water at higher temperatures could also increase the ventilation at gills and the respiration rate (Jones et al., 1970), causing a larger quantity of water to move across the gill epithelium, thus increasing the possibility of greater uptake of contaminants from the medium and intensifying the stress.

From the result (Table-3 and 4) it is evident that the Catla catla and Labeo rohita showed behavioral alterations against Dimethoate intoxication. Uncoordinated movements, erratic swimming, convulsions, excess mucus secretion, decreased opercular movements, loss of balance, drowning and change in body pigmentation, muscle fasciculation. Moribund lethargy, refusal of feeding, respiratory distress became more apparent with increase in duration of exposure at all test concentration of Dimethoate.

The results of water quality of the tap water used in the present investigation were in the normal range which suggests that the parameters of the test water were not the cause of fish mortality. However, temperature, hardness, $\mathrm{pH}$, alkalinity and biological factors such as sex, age, health, weight and physiological status are reported to have profound effects on the acute toxicity of organophosphate pesticide, Dimethoate. The present findings gain support from the work of Singh 2013 and Singh (2009) who reported a more or less similar results on acute toxicity and behavioral response of Dimethoate to an air breathing fish, Colisa fasciatus and common carp, Cyprinus carpio respectively.

From the result (Table-5 and 6) it is evident that the glycogen content, total proteins and total lipids decreased in the blood of Catla catla and Labeo rohita under the toxicity of Dimethoate whereas the levels of total free sugars and total free amino acids increased. In animals, any stress could inflict excessive energy demand, which is immediately fulfilled by blood glucose. As a consequence, the blood sugar level could increase as observed in the present experimental fish, Catla catla and Labeo rihita. As a consequence, the glycogen reserve in the blood could be subjected to glycogenolysis with the resultant depletion. This is in conformity with the findings of Mukhopadhyay and Dehadrai (1980), Parithabhanu and Subramanian (2006) and Natarajan (1989) in pesticide- treated fishes. The reduction in the glycogen content in the blood of present experimental fish, Catla catla and Labeo rohita could also be due to the inhibition of glycogenesis, as also observed by Kabeer et al., (1984) in bivalves treated with pesticide.

In the present investigation, Dimethoate caused reduction in total proteins in the blood of both Catla catla and Labeo rohita. The control fish showed $75.00 \mathrm{mg} / \mathrm{dL}$ of total proteins in their blood. The reduction in total proteins in blood of Catla catla at different concentrations of Dimethoate on $48 \mathrm{hrs}$ of exposure was recorded in the following sequence (Table-5): 
Table.1 Percentage lethality of Catla catla after exposure to eight different concentrations of Dimethoate

\begin{tabular}{|c|c|c|c|}
\hline $\begin{array}{l}\text { Concentration of } \\
\text { Dimethoate in } \mathrm{mg} / \mathrm{l} \\
\end{array}$ & $\begin{array}{l}\text { Time of exposure } \\
\text { in hrs. }\end{array}$ & $\begin{array}{l}\text { Number of fish } \\
\text { died out of ten }\end{array}$ & \% death \\
\hline \multirow{4}{*}{20.5} & 24 & 0 & 0 \\
\hline & 48 & 1 & 10 \\
\hline & 72 & 3 & 30 \\
\hline & 96 & 4 & 40 \\
\hline \multirow[t]{4}{*}{21.0} & 24 & 1 & 10 \\
\hline & 48 & 2 & 20 \\
\hline & 72 & 4 & 40 \\
\hline & 96 & 6 & 60 \\
\hline \multirow{4}{*}{21.5} & 24 & 2 & 20 \\
\hline & 48 & 2 & 20 \\
\hline & 72 & 5 & 50 \\
\hline & 96 & 7 & 70 \\
\hline \multirow[t]{4}{*}{22.0} & 24 & 2 & 20 \\
\hline & 48 & 3 & 30 \\
\hline & 72 & 6 & 60 \\
\hline & 96 & 8 & 80 \\
\hline \multirow[t]{4}{*}{22.5} & 24 & 3 & 30 \\
\hline & 48 & 5 & 50 \\
\hline & 72 & 6 & 60 \\
\hline & 96 & 9 & 90 \\
\hline \multirow[t]{4}{*}{23.0} & 24 & 3 & 30 \\
\hline & 48 & 5 & 50 \\
\hline & 72 & 7 & 70 \\
\hline & 96 & 10 & 100 \\
\hline \multirow[t]{4}{*}{23.5} & 24 & 5 & 50 \\
\hline & 48 & 7 & 70 \\
\hline & 72 & 9 & 90 \\
\hline & 96 & 10 & 100 \\
\hline \multirow[t]{4}{*}{24.0} & 24 & 5 & 50 \\
\hline & 48 & 7 & 70 \\
\hline & 72 & 9 & 90 \\
\hline & 96 & 10 & 100 \\
\hline
\end{tabular}


Table.2 Percentage lethality of Catla catla after exposure to eight different concentrations of Dimethoate

\begin{tabular}{|c|c|c|c|}
\hline $\begin{array}{l}\text { Concentration of } \\
\text { Dimethoate in } \mathrm{mg} / \mathrm{l}\end{array}$ & $\begin{array}{l}\text { Time of exposure } \\
\text { in hrs. }\end{array}$ & $\begin{array}{l}\text { Number of fish } \\
\text { died out of ten }\end{array}$ & $\%$ death \\
\hline \multirow{4}{*}{20.5} & 24 & 0 & 0 \\
\hline & 48 & 1 & 10 \\
\hline & 72 & 3 & 30 \\
\hline & 96 & 5 & 50 \\
\hline \multirow[t]{4}{*}{21.0} & 24 & 1 & 10 \\
\hline & 48 & 2 & 20 \\
\hline & 72 & 5 & 50 \\
\hline & 96 & 7 & 70 \\
\hline \multirow{4}{*}{21.5} & 24 & 2 & 20 \\
\hline & 48 & 5 & 50 \\
\hline & 72 & 6 & 60 \\
\hline & 96 & 8 & 80 \\
\hline \multirow[t]{4}{*}{22.0} & 24 & 3 & 30 \\
\hline & 48 & 5 & 50 \\
\hline & 72 & 7 & 70 \\
\hline & 96 & 8 & 80 \\
\hline \multirow[t]{4}{*}{22.5} & 24 & 3 & 30 \\
\hline & 48 & 5 & 50 \\
\hline & 72 & 7 & 70 \\
\hline & 96 & 9 & 90 \\
\hline \multirow[t]{4}{*}{23.0} & 24 & 5 & 50 \\
\hline & 48 & 6 & 60 \\
\hline & 72 & 8 & 80 \\
\hline & 96 & 10 & 100 \\
\hline \multirow[t]{4}{*}{23.5} & 24 & 5 & 50 \\
\hline & 48 & 8 & 80 \\
\hline & 72 & 9 & 90 \\
\hline & 96 & 10 & 100 \\
\hline \multirow[t]{4}{*}{24.0} & 24 & 5 & 50 \\
\hline & 48 & 7 & 70 \\
\hline & 72 & 10 & 100 \\
\hline & 96 & 10 & 100 \\
\hline
\end{tabular}


Table.3 Behavioral response of Catla catla after exposure to eight different concentrations of Dimethoate

\begin{tabular}{|c|c|c|c|c|c|c|c|c|c|c|c|c|c|c|c|c|}
\hline \multirow{4}{*}{$\begin{array}{l}\text { Symptoms } \\
\text { observed }\end{array}$} & \multicolumn{16}{|c|}{ Concentration of Dimethoate in $\mathrm{mg} / \mathrm{l}$} \\
\hline & \multicolumn{4}{|c|}{20.5} & \multicolumn{4}{|c|}{21.0} & \multicolumn{4}{|c|}{21.5} & \multicolumn{4}{|l|}{22.0} \\
\hline & \multicolumn{16}{|c|}{ Time of exposure } \\
\hline & 24 & 48 & 72 & 96 & 24 & 48 & 72 & 96 & 24 & 48 & 72 & 96 & 24 & 48 & 72 & 96 \\
\hline Lethargy & + & + & ++ & $\mathrm{M}$ & + & ++ & +++ & $\mathrm{M}$ & + & ++ & $\mathrm{M}$ & $\mathrm{M}$ & ++ & +++ & $\mathrm{M}$ & $\mathrm{L}$ \\
\hline $\begin{array}{l}\text { Increased } \\
\text { mucus }\end{array}$ & + & ++ & ++ & +++ & + & ++ & +++ & +++ & ++ & +++ & +++ & +++ & +++ & +++ & +++ & +++ \\
\hline $\begin{array}{l}\text { Skin } \\
\text { discoloration }\end{array}$ & - & + & + & ++ & + & ++ & ++ & +++ & - & + & ++ & ++ & ++ & +++ & +++ & +++ \\
\hline $\begin{array}{l}\text { Muscle } \\
\text { fasciculation }\end{array}$ & + & + & ++ & +++ & + & ++ & +++ & +++ & + & ++ & +++ & +++ & +++ & +++ & +++ & +++ \\
\hline $\begin{array}{l}\text { Respiratory } \\
\text { distress }\end{array}$ & + & + & ++ & ++ & + & ++ & ++ & +++ & ++ & +++ & +++ & +++ & +++ & +++ & +++ & +++ \\
\hline $\begin{array}{l}\text { Feeding } \\
\text { behavior }\end{array}$ & $\mathrm{N}$ & $\mathrm{N}$ & $\mathrm{N}$ & $\mathrm{N}$ & $\mathrm{N}$ & $\mathrm{N}$ & LA & LA & $\mathrm{N}$ & LA & LA & LA & LA & LA & LA & $\mathrm{RF}$ \\
\hline
\end{tabular}

\begin{tabular}{|c|c|c|c|c|c|c|c|c|c|c|c|c|c|c|c|c|}
\hline \multirow{4}{*}{$\begin{array}{l}\text { Symptoms } \\
\text { observed }\end{array}$} & \multicolumn{16}{|c|}{ Concentration of Dimethoate in $\mathrm{mg} / \mathrm{l}$} \\
\hline & \multicolumn{4}{|c|}{22.5} & \multicolumn{4}{|c|}{23.0} & \multicolumn{4}{|l|}{23.5} & \multicolumn{4}{|l|}{24.0} \\
\hline & \multicolumn{16}{|c|}{ Time of exposure in hrs. } \\
\hline & 24 & 48 & 72 & 96 & 24 & 48 & 72 & 96 & 24 & 48 & 72 & 96 & 24 & 48 & 72 & 96 \\
\hline Lethargy & +++ & $\mathrm{M}$ & $\mathrm{L}$ & $\mathrm{L}$ & $\mathrm{M}$ & $\mathrm{L}$ & $\mathrm{L}$ & $\mathrm{L}$ & $\mathrm{L}$ & $\mathrm{L}$ & $\mathrm{L}$ & $\mathrm{L}$ & $\mathrm{L}$ & $\mathrm{L}$ & $\mathrm{L}$ & $\mathrm{L}$ \\
\hline $\begin{array}{l}\text { Increased } \\
\text { mucus }\end{array}$ & +++ & +++ & +++ & +++ & +++ & +++ & +++ & +++ & +++ & +++ & +++ & +++ & +++ & +++ & +++ & +++ \\
\hline $\begin{array}{l}\text { Skin } \\
\text { discoloration }\end{array}$ & +++ & +++ & +++ & +++ & +++ & +++ & +++ & +++ & +++ & +++ & +++ & ++ & +++ & +++ & +++ & +++ \\
\hline $\begin{array}{l}\text { Muscle } \\
\text { fasciculation }\end{array}$ & +++ & +++ & +++ & +++ & +++ & +++ & +++ & +++ & +++ & +++ & +++ & +++ & +++ & +++ & +++ & +++ \\
\hline $\begin{array}{l}\text { Respiratory } \\
\text { distress }\end{array}$ & +++ & +++ & +++ & +++ & +++ & +++ & +++ & +++ & +++ & +++ & +++ & +++ & +++ & +++ & +++ & +++ \\
\hline $\begin{array}{l}\text { Feeding } \\
\text { behavior }\end{array}$ & LA & LA & $\mathrm{RF}$ & $\mathrm{RF}$ & LA & $\mathrm{RF}$ & $\mathrm{RF}$ & $\mathrm{RF}$ & $\mathrm{RF}$ & $\mathrm{RF}$ & $\mathrm{RF}$ & $\mathrm{RF}$ & $\mathrm{RF}$ & $\mathrm{RF}$ & $\mathrm{RF}$ & $\mathrm{RF}$ \\
\hline
\end{tabular}

Degree of intensity of the symptoms: '+' above normal; '++' moderate; '+++' severe' $M$ ' moribund;

'L' lethal; 'N' normal feeding; 'LA' loss of appetite; 'RF' refusal of feed 
Table.4 Behavioral response of Labeo rohita after exposure to eight different concentrations of Dimethoate

\begin{tabular}{|c|c|c|c|c|c|c|c|c|c|c|c|c|c|c|c|c|}
\hline \multirow{4}{*}{$\begin{array}{l}\text { Symptoms } \\
\text { observed }\end{array}$} & \multicolumn{16}{|c|}{ Concentration of Dimethoate in $\mathrm{mg} / \mathrm{l}$} \\
\hline & \multicolumn{4}{|c|}{20.5} & \multicolumn{4}{|c|}{21.0} & \multicolumn{4}{|c|}{21.5} & \multicolumn{4}{|l|}{22.0} \\
\hline & \multicolumn{16}{|c|}{ Time of exposure } \\
\hline & 24 & 48 & 72 & 96 & 24 & 48 & 72 & 96 & 24 & 48 & 72 & 96 & 24 & 48 & 72 & 96 \\
\hline Lethargy & + & ++ & ++ & $\mathrm{M}$ & ++ & ++ & +++ & $\mathrm{M}$ & + & ++ & $\mathrm{M}$ & $\mathrm{M}$ & ++ & +++ & $\mathrm{M}$ & $\mathrm{L}$ \\
\hline $\begin{array}{l}\text { Increased } \\
\text { mucus }\end{array}$ & + & ++ & ++ & +++ & ++ & +++ & +++ & +++ & ++ & +++ & +++ & +++ & +++ & +++ & +++ & +++ \\
\hline $\begin{array}{l}\text { Skin } \\
\text { discoloration }\end{array}$ & - & + & ++ & +++ & ++ & +++ & ++ & +++ & + & + & ++ & ++ & ++ & +++ & +++ & +++ \\
\hline $\begin{array}{l}\text { Muscle } \\
\text { fasciculation }\end{array}$ & + & + & ++ & +++ & ++ & +++ & +++ & +++ & + & ++ & +++ & +++ & +++ & +++ & +++ & +++ \\
\hline $\begin{array}{l}\text { Respiratory } \\
\text { distress }\end{array}$ & + & + & ++ & +++ & ++ & +++ & ++ & +++ & ++ & +++ & +++ & +++ & +++ & +++ & +++ & +++ \\
\hline $\begin{array}{l}\text { Feeding } \\
\text { behavior }\end{array}$ & $\mathrm{N}$ & $\mathrm{N}$ & $\mathrm{N}$ & $\mathrm{N}$ & $\mathrm{N}$ & $\mathrm{N}$ & LA & LA & $\mathrm{N}$ & LA & LA & LA & LA & LA & LA & $\mathrm{RF}$ \\
\hline
\end{tabular}

\begin{tabular}{|c|c|c|c|c|c|c|c|c|c|c|c|c|c|c|c|c|}
\hline \multirow{4}{*}{$\begin{array}{l}\text { Symptoms } \\
\text { observed }\end{array}$} & \multicolumn{16}{|c|}{ Concentration of Dimethoate in $\mathrm{mg} / \mathrm{l}$} \\
\hline & 22.5 & & & & 23.0 & & & & 23.5 & & & & 24.0 & & & \\
\hline & \multicolumn{16}{|c|}{ Time of exposure in hrs. } \\
\hline & 24 & 48 & 72 & 96 & 24 & 48 & 72 & 96 & 24 & 48 & 72 & 96 & 24 & 48 & 72 & 96 \\
\hline Lethargy & +++ & $\mathrm{M}$ & $\mathrm{L}$ & $\mathrm{L}$ & $\mathrm{M}$ & $\mathrm{L}$ & $\mathrm{L}$ & $\mathrm{L}$ & $\mathrm{L}$ & $\mathrm{L}$ & $\mathrm{L}$ & $\mathrm{L}$ & $\mathrm{L}$ & $\mathrm{L}$ & $\mathrm{L}$ & $\mathrm{L}$ \\
\hline $\begin{array}{l}\text { Increased } \\
\text { mucus }\end{array}$ & +++ & +++ & +++ & +++ & +++ & +++ & +++ & +++ & +++ & +++ & +++ & +++ & +++ & +++ & +++ & +++ \\
\hline $\begin{array}{l}\text { Skin } \\
\text { discoloration }\end{array}$ & +++ & +++ & +++ & +++ & +++ & +++ & +++ & +++ & +++ & +++ & +++ & +++ & +++ & +++ & +++ & +++ \\
\hline $\begin{array}{l}\text { Muscle } \\
\text { fasciculation }\end{array}$ & +++ & +++ & +++ & +++ & +++ & +++ & +++ & +++ & +++ & +++ & +++ & +++ & +++ & +++ & +++ & +++ \\
\hline $\begin{array}{l}\text { Respiratory } \\
\text { distress }\end{array}$ & +++ & +++ & +++ & +++ & +++ & +++ & +++ & +++ & +++ & +++ & +++ & +++ & +++ & +++ & +++ & +++ \\
\hline $\begin{array}{l}\text { Feeding } \\
\text { behavior }\end{array}$ & LA & $\mathrm{LA}$ & $\mathrm{RF}$ & $\mathrm{RF}$ & LA & $\mathrm{RF}$ & $\mathrm{RF}$ & $\mathrm{RF}$ & $\mathrm{RF}$ & $\mathrm{RF}$ & $\mathrm{RF}$ & $\mathrm{RF}$ & $\mathrm{RF}$ & $\mathrm{RF}$ & RF & $\mathrm{RF}$ \\
\hline
\end{tabular}

Degree of intensity of the symptoms: '+' above normal; '++' moderate; '+++' severe

'M' moribund; 'L' lethal; 'N' normal feeding; 'LA' loss of appetite; 'RF' refusal of feed 
Table.5 Biochemical composition of blood serum of Catla catla in control and 48 hrs. Of exposure to eight different concentrations of Dimethoate

\begin{tabular}{|c|c|c|c|c|c|}
\hline $\begin{array}{l}\text { Concentration } \\
\text { of Dimethoate } \\
\text { in } \mathrm{mg} / \mathrm{l}\end{array}$ & $\begin{array}{l}\text { Total free } \\
\text { amino acids in } \\
\mathrm{mg} / \mathrm{l}\end{array}$ & $\begin{array}{l}\text { Total proteins } \\
\text { in } \mathrm{mg} / \mathrm{l}\end{array}$ & $\begin{array}{l}\text { Glycogen in } \\
\text { mg/l }\end{array}$ & $\begin{array}{l}\text { Total free } \\
\text { sugars in mg/l }\end{array}$ & $\begin{array}{l}\text { Total lipids in } \\
\mathrm{mg} / \mathrm{l}\end{array}$ \\
\hline Control & $455.00 \pm 11.63$ & $75.00 \pm 5.54$ & $20.75 \pm 1.45$ & $150.00 \pm 6.11$ & $396.65 \pm 15.41$ \\
\hline 20.5 & $\begin{array}{l}475.00 \pm 14.26 \mathrm{NS} \\
(+4.85 ; r=0.75)\end{array}$ & $\begin{array}{l}72.80 \pm 1.35 \\
(-14.31 ; r=1.00\end{array}$ & $\begin{array}{l}17.60 \pm 1.45^{*} \\
(-18.04 ; \\
r=0.55)\end{array}$ & $\begin{array}{l}161.00 \pm 10.15 N S \\
(+10.05 ; r=0.32)\end{array}$ & $\begin{array}{l}258 \pm 22.11 N S \\
(-9.59 ; r=0.75)\end{array}$ \\
\hline 21.0 & $\begin{array}{l}485.00 \pm 12.21 \mathrm{NS} \\
(+11.75 ; r=0.51)\end{array}$ & $\begin{array}{l}61.65 \pm 1.35 \\
(-12.12 \\
r=0.41)\end{array}$ & $\begin{array}{l}15.45 \pm 1.35 \\
(-20.05 \\
r=0.70)\end{array}$ & $\begin{array}{l}175.00 \pm 9.75^{*} \\
(+20.55 ; r=0.07)\end{array}$ & $\begin{array}{l}345 \pm 21.24^{*} \\
(-13.38 ; r=0.61)\end{array}$ \\
\hline 21.5 & $\begin{array}{l}505.00 \pm 11.25^{*} \\
(+21.11 ; r=0.81)\end{array}$ & $\begin{array}{l}52.25 \pm 1.65 \\
(-31.65 \\
r=0.44)\end{array}$ & $\begin{array}{l}11.20 \pm 1.15^{*} \\
(-25.21 ; \\
r=0.91)\end{array}$ & $\begin{array}{l}205.00 \pm 9.62 * \\
(+26.31 ; r=.031)\end{array}$ & $\begin{array}{l}312 \pm 11.65^{*} \\
(-16.21 ; r=0.61)\end{array}$ \\
\hline 22.0 & $\begin{array}{l}515.00 \pm 12.65 \\
(+31.15 ; r=0.65)\end{array}$ & $\begin{array}{l}45.00 \pm 1.65^{*} \\
(-34.51 ; \\
r=0.45)\end{array}$ & $\begin{array}{l}9.35 \pm 1.16 \\
(-30.22 ; \\
r=0.91)\end{array}$ & $\begin{array}{l}225.00 \pm 10.61 \\
(+32.35 ; r=0.38)\end{array}$ & $\begin{array}{l}286.45 \pm 17.64^{*} \\
(-21.51 ; r=0.61)\end{array}$ \\
\hline 22.5 & $\begin{array}{l}545.00 \pm 6.58^{*} \\
(+33.15 ; r=0.51)\end{array}$ & $\begin{array}{l}38.80 \pm 1.17^{*} \\
(-38.81 ; \\
\text { r=0.15) }\end{array}$ & $\begin{array}{l}7.35 \pm 1.21^{*} \\
(-36.15 \\
r=0.91)\end{array}$ & $\begin{array}{l}237.00 \pm 11.50 * \\
(+35.15 ; r=0.45)\end{array}$ & $\begin{array}{l}205.55 \pm 16.64^{*} \\
(-27.51 ; r=0.52)\end{array}$ \\
\hline 23.0 & $\begin{array}{l}576.25 \pm 7.45^{*} \\
(+36.14 ; r=0.53)\end{array}$ & $\begin{array}{l}30.70 \pm 1.16{ }^{*} \\
(-42.35 ; \\
r=0.18)\end{array}$ & $\begin{array}{l}6.35 \pm 1.25^{*} \\
(-40.16 \\
r=0.71)\end{array}$ & $\begin{array}{l}247.00 \pm 15.12^{*} \\
(+43.12 ; r=0.73)\end{array}$ & $\begin{array}{l}195.16 \pm 11.65^{*} \\
(-32.35 ; r=0.61)\end{array}$ \\
\hline 23.5 & $\begin{array}{l}612 \pm 7.46 \\
(+38.12 ; r=.0 .64)\end{array}$ & $\begin{array}{l}27.00 \pm 2.35^{*} \\
(-45.81 ; \\
r=0.15)\end{array}$ & $\begin{array}{l}5.27 \pm 1.35^{*} \\
(-42.15 \\
r=0.81)\end{array}$ & $\begin{array}{l}255.10 \pm 11.15^{*} \\
(+45.15 ; r=0.72)\end{array}$ & $\begin{array}{l}187.14 \pm 11.50 \\
(-41.21 ; r=0.51)\end{array}$ \\
\hline 24.0 & $\begin{array}{l}630.00 \pm 13.25^{*} \\
(48.56 ; r=0.85)\end{array}$ & $\begin{array}{l}21.25 \pm 2.75 \\
(-51.95 \\
r=0.95)\end{array}$ & $\begin{array}{l}4.58 \pm 1.27^{*} \\
(-45.16 \\
r=0.71)\end{array}$ & $\begin{array}{l}272.15 \pm 7.15^{*} \\
(+48.12 ; r=0.62)\end{array}$ & $\begin{array}{l}179.27 \pm 10.90 \\
(-46.25 ; r=0.61)\end{array}$ \\
\hline
\end{tabular}

Table.6 Biochemical composition of blood serum of Labeo rohita in control and 48 hrs. Of exposure to eight different concentrations of Dimethoate

\begin{tabular}{|c|c|c|c|c|c|}
\hline $\begin{array}{l}\text { Concentration } \\
\text { of Dimethoate } \\
\text { in } \mathrm{mg} / \mathrm{l}\end{array}$ & $\begin{array}{l}\text { Total free amino } \\
\text { acids in } \mathrm{mg} / \mathrm{l}\end{array}$ & $\begin{array}{l}\text { Total proteins } \\
\text { in } \mathrm{mg} / \mathrm{l}\end{array}$ & $\begin{array}{l}\text { Glycogen in } \\
\mathrm{mg} / \mathrm{l}\end{array}$ & $\begin{array}{l}\text { Total free } \\
\text { sugars in mg/l }\end{array}$ & $\begin{array}{l}\text { Total lipids in } \\
\mathrm{mg} / \mathrm{l}\end{array}$ \\
\hline Control & $450.00 \pm 11.63$ & $70.00 \pm 5.54$ & $18.75 \pm 1.45$ & $140.00 \pm 6.11$ & $390.65 \pm 15.41$ \\
\hline 20.5 & $\begin{array}{l}470.00 \pm 14.26 \mathrm{NS} \\
(+4.85 ; r=0.75)\end{array}$ & $\begin{array}{l}69.80 \pm 1.35^{*} \\
(-14.31 ; r=1.00\end{array}$ & $\begin{array}{l}17.60 \pm 1.45^{*} \\
(-18.04 \\
r=0.55)\end{array}$ & $\begin{array}{l}160.00 \pm 10.15 N S \\
(+10.05 ; r=0.32)\end{array}$ & $\begin{array}{l}268 \pm 22.11 N S \\
(-9.59 ; r=0.75)\end{array}$ \\
\hline 21.0 & $\begin{array}{l}485.00 \pm 12.21 N S \\
(+11.75 ; r=0.51)\end{array}$ & $\begin{array}{l}61.65 \pm 1.35^{*} \\
(-12.12 \\
r=0.41)\end{array}$ & $\begin{array}{l}15.45 \pm 1.35^{*} \\
(-20.05 ; \\
\text { r=0.70) }\end{array}$ & $\begin{array}{l}175.00 \pm 9.75^{*} \\
(+20.55 ; r=0.07)\end{array}$ & $\begin{array}{l}345 \pm 21.24^{*} \\
(-13.38 ; r=0.61)\end{array}$ \\
\hline 21.5 & $\begin{array}{l}501.00 \pm 11.25^{*} \\
(+21.11 ; r=0.81)\end{array}$ & $\begin{array}{l}51.25 \pm 1.65^{*} \\
(-31.65 ; \\
r=0.44)\end{array}$ & $\begin{array}{l}10.20 \pm 1.15^{*} \\
(-25.21 \\
r=0.91)\end{array}$ & $\begin{array}{l}203.00 \pm 9.62 * \\
(+26.31 ; r=.031)\end{array}$ & $\begin{array}{l}308 \pm 11.65^{*} \\
(-16.21 ; r=0.61)\end{array}$ \\
\hline 22.0 & $\begin{array}{l}512.00 \pm 12.65 \\
(+31.15 ; r=0.65)\end{array}$ & $\begin{array}{l}42.5 \pm 1.65^{*} \\
(-34.51 ; \\
r=0.45)\end{array}$ & $\begin{array}{l}9.25 \pm 1.16^{*} \\
(-30.22 ; \\
r=0.91)\end{array}$ & $\begin{array}{l}220.00 \pm 10.61^{*} \\
(+32.35 ; r=0.38)\end{array}$ & $\begin{array}{l}281.45 \pm 17.64^{*} \\
(-21.51 ; r=0.61)\end{array}$ \\
\hline 22.5 & $\begin{array}{l}543.00 \pm 6.58 \\
(+33.15 ; r=0.51)\end{array}$ & $\begin{array}{l}37.80 \pm 1.17^{*} \\
(-38.81 ; \\
r=0.15)\end{array}$ & $\begin{array}{l}8.35 \pm 1.21 \\
(-36.15 ; \\
r=0.91)\end{array}$ & $\begin{array}{l}231.00 \pm 11.50 \\
(+35.15 ; r=0.45)\end{array}$ & $\begin{array}{l}202.55 \pm 16.64^{*} \\
(-27.51 ; r=0.52)\end{array}$ \\
\hline 23.0 & $\begin{array}{l}574.25 \pm 7.45^{*} \\
(+36.14 ; r=0.53)\end{array}$ & $\begin{array}{l}30.60 \pm 1.16 \\
(-42.35 \\
r=0.18)\end{array}$ & $\begin{array}{l}6.25 \pm 1.25^{*} \\
(-40.16 ; \\
r=0.71)\end{array}$ & $\begin{array}{l}251.00 \pm 15.12^{*} \\
(+43.12 ; r=0.73)\end{array}$ & $\begin{array}{l}185.16 \pm 11.65^{*} \\
(-32.35 ; r=0.61)\end{array}$ \\
\hline 23.5 & $\begin{array}{l}609 \pm 7.46^{*} \\
(+38.12 ; r=.0 .64)\end{array}$ & $\begin{array}{l}28.00 \pm 2.35^{*} \\
(-45.81 ; \\
r=0.15)\end{array}$ & $\begin{array}{l}6.27 \pm 1.35 \\
(-42.15 \\
r=0.81)\end{array}$ & $\begin{array}{l}245.10 \pm 11.15^{*} \\
(+45.15 ; r=0.72)\end{array}$ & $\begin{array}{l}185.14 \pm 11.50 \\
(-41.21 ; r=0.51)\end{array}$ \\
\hline 24.0 & $\begin{array}{l}627.00 \pm 13.25^{*} \\
(48.56 ; r=0.85)\end{array}$ & $\begin{array}{l}20.25 \pm 2.75 \\
(-51.95 ; \\
r=0.95)\end{array}$ & $\begin{array}{l}4.45 \pm 1.27^{*} \\
(-45.16 ; \\
r=0.71)\end{array}$ & $\begin{array}{l}270.15 \pm 7.15^{*} \\
(+48.12 ; r=0.62)\end{array}$ & $\begin{array}{l}175.27 \pm 10.90 \\
(-46.25 ; r=0.61)\end{array}$ \\
\hline
\end{tabular}


Table.7 Haematological profiles of Catla catla and Labeo rohita affected by acute exposure to Dimethoate

\begin{tabular}{|l|l|l|l|l|}
\hline \multirow{2}{*}{ Indices } & \multicolumn{2}{|l|}{ Catla catla } & Labeo rohita \\
\cline { 2 - 5 } & $\begin{array}{l}\text { Control, } \\
\mathrm{n}=15, X \pm \mathrm{SD}\end{array}$ & $\begin{array}{l}\text { Experimental } \\
\text { group, } \mathrm{n}=15, \\
X \pm \mathrm{SD}\end{array}$ & $\begin{array}{l}\text { Control, } \\
\mathrm{n}=15, X \pm \mathrm{SD}\end{array}$ & $\begin{array}{l}\text { Experimental } \\
\text { group, }=15, \\
X \pm \mathrm{SD}\end{array}$ \\
\hline $\mathrm{RBC}(\mathrm{T} / \mathrm{l})$ & $0.80 \pm 0.15^{\mathrm{a}}$ & $0.78 \pm 0.24^{\mathrm{a}}$ & $0.75 \pm 0.12^{\mathrm{a}}$ & $0.71 \pm 0.15^{\mathrm{a}}$ \\
\hline $\mathrm{Hb}(\mathrm{g} / \mathrm{l})$ & $41.71 \pm 6.39^{\mathrm{a}}$ & $42.69 \pm 10.30^{\mathrm{a}}$ & $37.51 \pm 3.15^{\mathrm{a}}$ & $32.50 \pm 0.18^{\mathrm{a}}$ \\
\hline $\mathrm{PCV}(1 / \mathrm{l})$ & $0.36 \pm 0.04^{\mathrm{a}}$ & $0.39 \pm 0.05^{\mathrm{a}}$ & $0.30 \pm 0.05^{\mathrm{a}}$ & $0.35 \pm 0.04^{\mathrm{a}}$ \\
\hline $\mathrm{MCV}(\mathrm{fl})$ & $460.57 \pm 8.82^{\mathrm{a}}$ & $568.15 \pm 2.91^{\mathrm{a}}$ & $428.25 \pm 6.88^{\mathrm{a}}$ & $455.15 \pm 2.51^{\mathrm{a}}$ \\
\hline $\mathrm{MCH}(\mathrm{pg})$ & $53.31 \pm 5.87^{\mathrm{a}}$ & $59.81 \pm 8.23^{\mathrm{a}}$ & $48.25 \pm 6.17^{\mathrm{a}}$ & $55.75 \pm 8.65^{\mathrm{a}}$ \\
\hline $\mathrm{MCH}(\mathrm{g} / \mathrm{l})$ & $115.8 .36^{\mathrm{a}}$ & $108.7 \pm 7.68 \mathrm{a}$ & $112.85 \pm 8.35^{\mathrm{a}}$ & $105.55 \pm 6.55^{\mathrm{a}}$ \\
\hline
\end{tabular}

Groups with different alphabetic superscripts differ significantly at $P<0.05$ (ANOVA)

Table.8 Leukocyte differential count of Catla catla and Labeo rohita affected by acute exposure to Dimethoate

\begin{tabular}{|l|l|l|l|l|}
\hline Indices & \multicolumn{2}{|l|}{ Catla catla } & \multicolumn{2}{l|}{ Labeo rohita } \\
\cline { 2 - 5 } & $\begin{array}{l}\text { Control, } \\
\mathrm{n}=15, X \pm \mathrm{SD}\end{array}$ & $\begin{array}{l}\text { Experimental } \\
\text { group, } \mathrm{n}=15, \\
X \pm \mathrm{SD}\end{array}$ & $\begin{array}{l}\text { Control, } \\
\mathrm{n}=15, X \pm \mathrm{SD}\end{array}$ & $\begin{array}{l}\text { Experimental } \\
\text { group, } \mathrm{n}=15, \\
X \pm \mathrm{SD}\end{array}$ \\
\hline Leukocyte (G/l) & $13.15 \pm 3.56^{\mathrm{a}}$ & $10.22 \pm 5.03^{\mathrm{a}}$ & $11.25 \pm 2.51^{\mathrm{a}}$ & $8.18 \pm 2.11^{\mathrm{a}}$ \\
\hline $\begin{array}{l}\text { Lymphocyte } \\
(\mathrm{G} / \mathrm{l})\end{array}$ & $12.54 \pm 3.11$ & $9.94 \pm 4.08^{\mathrm{a}}$ & $10.55 \pm 2.11^{\mathrm{a}}$ & $7.25 \pm 2.21^{\mathrm{a}}$ \\
\hline Monocyte(G/l) & $0.01 \pm 0.03^{\mathrm{a}}$ & $0.01 \pm 0.05^{\mathrm{a}}$ & $0.01 \pm 0.05^{\mathrm{a}}$ & $0.01 \pm 0.04^{\mathrm{a}}$ \\
\hline $\begin{array}{l}\text { Neutrophile } \\
\text { granilocute } \\
\text { segments (G/l) }\end{array}$ & $0.51 \pm 0.19^{\mathrm{a}}$ & $0.25 \pm 0.21^{\mathrm{b}}$ & $0.42 \pm 0.17^{\mathrm{a}}$ & $0.27 \pm 0.20^{\mathrm{b}}$ \\
\hline $\begin{array}{l}\text { Neutrophile } \\
\text { granilocute bands } \\
\text { (G/l) }\end{array}$ & $0.05 \pm 0.07^{\mathrm{a}}$ & $0.02 \pm 0.04^{\mathrm{a}}$ & $0.03 \pm 0.05^{\mathrm{a}}$ & $0.01 \pm 0.03^{\mathrm{a}}$ \\
\hline $\begin{array}{l}\text { Developmental } \\
\text { phases - myeloid } \\
\text { sequence (G/l) }\end{array}$ & $0.03 \pm 0.05^{\mathrm{a}}$ & $0.01 \pm 0.02^{\mathrm{b}}$ & $0.03 \pm 0.04^{\mathrm{b}}$ & $0.01 \pm 0.03^{\mathrm{b}}$ \\
\hline
\end{tabular}

Groups with different alphabetic superscripts differ significantly at $P<0.05$ (ANOVA) 
Table.9 Bioghemical profiles of blood plasma of Catla catla and Labeo rohita affected by acute exposure to Dimethoate

\begin{tabular}{|c|c|c|c|c|}
\hline \multirow[t]{2}{*}{ Indices } & \multicolumn{2}{|l|}{ Catla catla } & \multicolumn{2}{|l|}{ Labeo rohita } \\
\hline & $\begin{array}{l}\text { Control, } \\
\mathrm{n}=15, X \pm \mathrm{SD}\end{array}$ & $\begin{array}{l}\text { Experimental } \\
\text { group, } \mathrm{n}=15, \\
X \pm \mathrm{SD}\end{array}$ & $\begin{array}{l}\text { Control, } \\
\mathrm{n}=15, X \pm \mathrm{SD}\end{array}$ & $\begin{array}{l}\text { Experimental } \\
\text { group, } \mathrm{n}=15, \\
X \pm \mathrm{SD}\end{array}$ \\
\hline GLU (mmol/l) & $3.64 \pm 0.75 \mathrm{a}$ & $4.07 \pm 1.84 a$ & $3.55 \pm 0.15^{\mathrm{a}}$ & $4.70 \pm 1.12^{\mathrm{a}}$ \\
\hline $\mathrm{TP}(\mathrm{G} / \mathrm{l})$ & $36.60 \pm 5.14 \mathrm{a}$ & $39.33 \pm 4.30^{\mathrm{a}}$ & $35.45 \pm 4.10^{\mathrm{a}}$ & $40.15 \pm 2.10^{\mathrm{a}}$ \\
\hline $\operatorname{ALB}(\mathrm{G} / \mathrm{l})$ & $6.80 \pm 2.71 \mathrm{a}$ & $8.60 \pm 0.99^{\mathrm{a}}$ & $5.75 \pm 1.72 \mathrm{a}$ & $7.55 \pm 0.12^{\mathrm{a}}$ \\
\hline GLOB (G/1) & $29.80 \pm 2.81^{\mathrm{a}}$ & $30.87 \pm 2.47^{\mathrm{a}}$ & $27.75 \pm 2.18^{\mathrm{a}}$ & $30.15 \pm 2.15^{\mathrm{a}}$ \\
\hline TRIG(mmol/l) & $0.97 \pm 0.12^{\mathrm{a}}$ & $0.86 \pm 0.19^{\mathrm{a}}$ & $0.95 \pm 0.15^{\mathrm{a}}$ & $0.82 \pm 0.14^{\mathrm{a}}$ \\
\hline ALT $(\mu \mathrm{kat} / \mathrm{l})$ & $0.08 \pm 0.02^{\mathrm{a}}$ & $0.08 \pm 0.02^{\mathrm{a}}$ & $0.07 \pm 0.04^{\mathrm{a}}$ & $0.07 \pm 0.03^{\mathrm{a}}$ \\
\hline $\mathrm{Ca}^{2+}(\mathrm{mmol} / \mathrm{l})$ & $2.53 \pm 0.18 \mathrm{a}$ & $2.81 \pm 0.38 \mathrm{a}$ & $2.13 \pm 0.15 \mathrm{a}$ & $2.70 \pm 0.31 \mathrm{a}$ \\
\hline. $\mathrm{ChE}(\mu \mathrm{kat} / \mathrm{l})$ & $2.03 \pm 1.30 \mathrm{a}$ & $2.52 \pm 0.99 \mathrm{a}$ & $2.00 \pm 0.95 \mathrm{a}$ & $2.48 \pm 0.71 \mathrm{a}$ \\
\hline PHOS $(\mathrm{mmol} / \mathrm{l})$ & $1.46 \pm 0.22 \mathrm{a}$ & $1.39 \pm 0.16 \mathrm{a}$ & $1.40 \pm 0.25 \mathrm{a}$ & $1.36 \pm 0.11 \mathrm{a}$ \\
\hline $\mathrm{NH}_{3}(\mathrm{mmol} / \mathrm{l})$ & 555 & $720 * *$ & 515 & $630 * *$ \\
\hline
\end{tabular}

Groups with different alphabetic superscripts differ significantly at $P<0.05$ (ANOVA) Significant $* * P<0.01$

Table.10 Isoenzyme profiles of blood plasma of Catla catla and Labeo rohita affected by acute exposure to Dimethoate

\begin{tabular}{|l|l|l|l|l|}
\hline \multirow{2}{*}{ Indices } & \multicolumn{3}{|l|}{ Catla catla } & \multicolumn{2}{l|}{ Labeo rohita } \\
\cline { 2 - 5 } & $\begin{array}{l}\text { Control, } \\
\mathrm{n}=15, X \pm \mathrm{SD}\end{array}$ & $\begin{array}{l}\text { Experimental } \\
\text { group, } \mathrm{n}=15, \\
X \pm \mathrm{SD}\end{array}$ & $\begin{array}{l}\text { Control, } \\
\mathrm{n}=15, X \pm \mathrm{SD}\end{array}$ & $\begin{array}{l}\text { Experimental } \\
\text { group, } \mathrm{n}=15, \\
X \pm \mathrm{SD}\end{array}$ \\
\hline $\mathrm{AST}(\mu \mathrm{kat} / \mathrm{l})$ & $4.3 \pm 0.11$ & $6.0^{* *} \pm 0.15$ & $4.0 \pm 0.17$ & $6.5^{* *} \pm 0.07$ \\
\hline $\mathrm{LDH}(\mu \mathrm{kat} / \mathrm{l})$ & $18.0 \pm 0.15$ & $25.0^{* *} \pm 1.12$ & $15.5 \pm 0.6$ & $26.0^{* *} \pm 0.14$ \\
\hline $\mathrm{CK}(\mu \mathrm{kat} / \mathrm{l})$ & $11.0 \pm 0.12$ & $15.0^{* *} \pm 1.60$ & $10.0 \pm 0.41$ & $13.0^{* *} \pm 0.13$ \\
\hline $\mathrm{ALP}(\mu \mathrm{kat} / \mathrm{l})$ & $0.8 \pm 0.15$ & $0.65^{* *} \pm 1.23$ & $0.7 \pm 0.16$ & $0.63^{* *} \pm 0.17$ \\
\hline $\mathrm{ALCT}(\mathrm{mmol} / \mathrm{l})$ & $3.5 \pm 0.18$ & $9.5^{* *} \pm 1.05$ & $3.0 \pm 0.17$ & $8.5^{* *} \pm 0.15$ \\
\hline
\end{tabular}

Concentration of

$\begin{array}{lllllllll}\text { Dimethoate in mg/l } & 20.5 & 21.0 & 21.5 & 22.0 & 22.5 & 23.0 & 23.5 & 24.0\end{array}$ $\begin{array}{lllllllll}\text { Total proteins } & \mathbf{7 2 . 8 0} & \mathbf{6 1 . 6 5} & \mathbf{5 2 . 2 5} & \mathbf{4 5 . 0 0} & \mathbf{3 8 . 8 0} & \mathbf{3 0 . 7 0} & \mathbf{2 7 . 0 0} & \mathbf{2 1 . 2 5}\end{array}$ in $\mathbf{~ m g / d L}$

Similarly the reduction in total proteins in blood of Labeo rohita at different concentrations of Dimethoate on $48 \mathrm{hrs}$ of exposure was recorded in the following sequence (Table-6):

\section{Concentration of \\ $\begin{array}{llllllllll}\text { Dimethoate in mg/l } & 20.5 & 21.0 & 21.5 & 22.0 & 22.5 & 23.0 & 23.5 & 24.0\end{array}$ $\begin{array}{lllllllll}\text { Total proteins } & 70.0 & 61.0 & \mathbf{5 1 . 2 5} & \mathbf{4 2 . 5 0} & \mathbf{3 7 . 8 0} & \mathbf{3 0 . 6 0} & \mathbf{2 8 . 0 0} & \mathbf{2 0 . 2 5}\end{array}$ in $\mathbf{~} g / \mathbf{d L}$}


Similarly reduction in total glycogen content as compared to control was recorded and showed significant decline in its content $(4.58 \mathrm{mg} / \mathrm{dL})$ at $24.0 \mathrm{mg} / \mathrm{l}$ of Dimethoate on $48 \mathrm{hrs}$ of exposure. Reduction in total lipids in blood of Catla catla was recorded to be $179.27 \mathrm{mg} / \mathrm{dL}$ at $24.0 \mathrm{mg} / \mathrm{lof}$ Dimethoate on $48 \mathrm{hrs}$ of exposure as compared to control $(396.65 \mathrm{mg} / \mathrm{dL})$. A more or less similar result was observed in case of Labei rohita. Similarly increase in total amino acids and total free sugars were recorded to be $630.00 \mathrm{mg} / \mathrm{dL}$ and $272.15 \mathrm{mg} / \mathrm{dL}$ respectively at $24.0 \mathrm{mg} / \mathrm{l}$ Dimethoate on $24 \mathrm{hrs}$ of exposure as compared to control. A similar pattern of increase in total amino acids and total free sugars was recorded in Labeo rohita after Dimethoate exposure at concentration of $24.0 \mathrm{mg} / \mathrm{l}$ for $24 \mathrm{hrs}$. This is suggestive of degradation of proteins and glycogen with the resultant increase of total free amino acids and sugars. The present findings gain support from the work of Kabeer et al., (1984) in pesticide- treated mollusks and Joyce Shoba Rani and Janaiah (1991) in Clarius batrachus under pesticide toxicity. Nagabhushanam et al., (1983) has reported that the free amino acids serve as supplementary energy source under the condition of emergency during chronic stress.

The decline in the total lipids in the blood of Catla catla and Labeo rohita under study indicates the utilization of lipids to meet the energy demand during the stress caused by Dimethoate (Table-5 and 6). According to Srinivas et al., (1991), the endogenous fat is the only source of energy requirements in animals during prolonged stress. This is in agreement with the findings of Jeba Kumar (1993) and Govindan (1994) who have reported the decrement of lipids in the tissues of fishes during stress caused by insecticides. Thus Dimethoate has disrupted the normal functioning of cells with resultant alterations in the fundamental biochemical mechanisms in fishes. This in turn would result in the mortality of fishes on prolonged exposure to the Dimethoate, an organophosphate.

The results of haematological profile of the control and experimental fish, Catla catla and Labeo rohita under the study period are given in Table 7. Compared to the control specimens, those after the acute exposure to Dimethoate at the concentration of $23 \mathrm{mg} / \mathrm{l}$ had no effect on the haematological indices studied (RBC, Hb, PCV, MCV, MCHC, $\mathrm{MCH}$ and Leuko). It was evident that the acute exposure to Dimethoate resulted in a significant decrease in count of developmental forms of myeloid sequence and the segmented neutrophilic granulocytes in the experimental group. The results of examinations of the leukocyte profile of control and experimental fish, Catla catla and Labeo rohita, are given in Table 8.

The results of biochemical blood plasma profile of the control and experimental fish Catla catla and Labeo rohita under the study period are given in Table- 9. The experimental fish, Catla catla and Labeo rohita exposed to acute effects of the Dimethoate insecticide showed significantly $(\mathrm{P}<0.01)$ decreased concentration of alkaline phosphatase and significantly $(\mathrm{P}<$ $0.01)$ increased concentration of ammonia, aspartate aminotransferase, lactate dehydrogenase,creatine kinase and lactate in blood plasma. The rest of the indices (GLU, TP, ALB, GLOB, TRIG, ALT, ChE, Ca2+, PHOS) were comparable in the two groups during the study (Table- 10). The present findings gain support from the work of Velisek et al., (2006), Bradbury and Coats (1989b), Davis et al., (1993), Polat et al., (2002), Masopust (2000) etc who also observed a more or less similar result in rainbow trout and other fish. 
In the present investigation with major carp, Catla catla and Labeo rohita, a significant decrease in count of developmental forms of myeloid sequence and the segmented neutrophilic granulocytes in the experimental group was observed. No significant differences were observed in the levels of RBC, $\mathrm{Hb}, \mathrm{PCV}, \mathrm{MCV}, \mathrm{MCHC}$, $\mathrm{MCH}$ and Leuko. However, Atamanalp et al. (2002a) and Atamanalp and Yanik (2003) found a significant increase $(\mathrm{P}<0.05)$ in the levels of $\mathrm{RBC}$ and a significant decrease $(\mathrm{P}$ $<0.05)$ in the $\mathrm{Hb}, \mathrm{MCH}, \mathrm{MCHC}$, thrombocyte count and erythrocyte in rainbow trout after exposure of cypermethrin insecticide. The main biochemical blood profile response of Catla catla and Labeo rohita to the acute effect of $23.5 \mathrm{mg} / \mathrm{l}$ of Dimethoate was a significantly $(\mathrm{P}<0.01)$ decreased concentration of alkaline phosphatase and significantly $(\mathrm{P}<$ 0.01 ) increased concentration of $\mathrm{NH} 3, \mathrm{LDH}$, AST, CK and LACT in blood plasma. Dimethoate caused an increase in plasma ammonia level perhaps due to an increase in amino acids catabolism and a failure of ammonia excretion mechanisms (Svoboda, 2001). The activities of enzymes in blood plasma can be also used as a relevant stress indicator. The enzymes used for the purpose are above all $\mathrm{LDH}, \mathrm{CK}$ and transaminases (ALT and AST). A significant increase in the activity of the above mentioned plasma enzymes indicate stress-based tissue impairment (Svoboda, 2001). After acute exposure to Dimethoate, a significant increase $(\mathrm{P}<0.01)$ in AST level was found in experimental carps in comparison to control specimens. Increased activities of both transaminases indicated amplified transamination processes. An increase in transamination occurs due to amino acid input into the TCA cycle in order to cope with the energy crisis during pyrethroidbased stress (Philip et al., 1995). The increase in $\mathrm{LDH}$ level indicated metabolic changes, i.e. the glycogen catabolism and glucose shift towards the formation of lactate in stressed fish, primarily in the muscle tissue (Simon et al., 1983). On the other hand, Atamanalp et al. (2002b) found changes in the concentration of calcium and phosphor in rainbow trout following cypermethrin exposure. Jee et al. (2005) found an increase in levels of serum glutamic-acid-oxylacetic-acid-transaminase, glutamic-acid-pyruvic-acid-transaminase, glucose and alkaline phosphatase and a decrease in the concentration of plasma total protein, albumin, cholesterol and lysozyme in Korean rockfish (Sebastes schlegeli) exposed to cypermethrin.

It is concluded that Dimethoate is highly toxic to fish which is greatly reflected in behavioral and biochemical alterations resulting in death. Further studies on toxicity of Dimethoate in laboratory and field on various fish species may help in deciding the judicious use of this insecticide.

\section{References}

Anoop Kumar Srivastava, Mishra, D., Shrivastava, S., Srivastava, S.K., Srivastava, A.K. 2010. Acute Toxicity and behavioral responses of Heteropeunistis fossilis to an organophosphate insecticide, Dimethoate, Int. J. Pharma and Biosci., 1(4): B-355- B363.

Arjmandi, R., Tavakol, M., Shayeghi, M. 2010. Determination of organophosphate insecticide residues in the rice paddies. Int. J. Environ. Sci. Technol., 7(1): 175- 182.

Atamanalp, M., Keles, M.S., Haliloglu, H.I., Aras, M.S. 2002b. The effects of cypermethrin (a synthetic pyrethroid) on some biochemical parameters $(\mathrm{Ca}$, $\mathrm{P}, \mathrm{Na}$ and $\mathrm{TP}$ ) of rainbow trout (Oncorhynchus mykiss). Turkish J. 
Vet. Ani. Sci., 26: 1157-1160.

Atamanalp, M., Yanik, T. 2003. Alterations

in hematological parameters of rainbow trout (Oncorhynchus mykiss) exposed to mancozeb. Turkish J. Vet. Ani. Sci., 27: 1213-1217.

Atamanalp, M., Yanik, T., Haliloglu, H.I., Aras, M.S. 2002a. Alternations in the hematological parameters of rainbow trout, Oncorhynchus mykiss, exposed to cypermethrin. Israeli $J$. Aquaculture, Bamidgeh, 54: 99-103.

Aysal, P., Tiryaki, O., Tuncbilek, A.S. 2004.

Dimethoate residues in tomato and tomato products. Bull. Environ. Contam. Toxicol., 351-357.

Bagheri, F. 2007. Study of pesticide residues (Diazinon, Azinphosmethyl) in the rivers of Golestan province (Gorgan Roud and Gharehsou), M. Sc thesis, Tehran Univ. Med. Sci., Tehran, 1125.

Banaee, M., Mirvagefei, R., Rafei, G.R., Majazi Amiri, B. 2008. Effect of sublethal Diazinon Concentrations on Blood Plasma Biochemistry. Int. J. Environ. Res., 2(2): 189-198.

Banaee, M., Mirvaghefei, A.R., Majazi Amiri, B., Rafei, G.R., Nematdost, B. 2011. Biochemical Blood and Histopathological Study of Experimental Diazinon Poisoning in common carp fish (Cyprinus carpio). J. Fisheries (Iranian Journal of Natural Resources), 64(1): 1-14.

Banaee, M., Mirvaghefi, A.R., Ahmadi, K. 2011. Effects of diazinon on biochemical parameters of blood in rainbow trout (Onchorhynchus mykiss). Pesticide Biochemistry and Physiology, 99: 1- 6.

Banaee, M., Mirvaghefi, A.R., Ahmadi, K., Ashori, R. 2009. The effect of diazinon on histopathological changes of testis and ovaries of common carp
(Cyprinus carpio). Scientific J. Marine Biol., 1(2): 25-35.

Banaee, M., Mirvaghefi, A.R., Ahmadi, K., Banaee, S. 2008. Determination of LC50 and investigation of acute toxicity effects of diazinon on hematology and serology indices of common carp (Cyprinus carpio). J. Marine Sci. Technol. Res., 3(2): 1- 10.

Barnes, Black stock, J. 1973. Estimation of lipids in marine animals and fish. Detailed investigation of the Sulphophosphovanillin method for total lipids. J. Exp. Mar. Biol. Ecol., 12: 103-118.

Begum, G. 1993. In vivo toxicity and accumulation of Dimethoate in freshwater fish Clarias batrachus (Linn.). Ph.D. thesis, Osmania University, Hyderabad A.P., India.

Begum, G. 2004. Carbofuran insecticide induced biochemical alterations in liver and muscle tissues of the fish Clarias batrachus (Linn) and recovery response. Aquatic Toxicol., 66: 83- 92.

Bradbury, S.P., Coats, J.R. 1989a. Comparative toxicology of the pyrethroid insecticides. Bulletin of Environmental Contamination and Toxicology, 108: 134-177.

Bradbury, S.P., Coats, J.R. 1989b. Toxicokinetics and toxicodynamics of pyrethroid insecticides in fish. Environ. Toxicol. Chem., 8: 373-380.

Breckenridge, C.B., Stevens, J.T. 2008. Crop Protection Chemicals: Mechanism of Action and Hazard Profiles. In: Principles and Methods of Toxicology (Ed. A.W. Hayes). CRC Press, Taylor and Francis Group, Boca Raton: 727-774.

C.C.M.E. (Canadian Council of Ministers of the Environment) 1999. Canadian water quality guidelines for the protection of aquatic life: Dimethoate. In: Canadian environmental quality 
guidelines, Canadian Council of Ministers of the Environment, Winnipeg.

Cerejeira, M.J., Viana, P., Batista, S., Pereira, T., Silva, E., Valerio, M.J., Silva, A., Ferreira, M., SilvaFernandes, A.M. 2003. Pesticides in Portuguese surface and ground waters. Water Res., Vol. 37, No. 5, (March 2003), pp. 1055-1063, ISSN 00431354.

Cope, W.G. 2004. Exposure Classes, Toxicants in Air, Water Soil, Domestic and Occupational Settings. In: AT. B. of Modern Toxicology (Ed. E. Hodgson). John Wiley and Sons Inc., New Jersey, USA: 33-48.

Davis, B.N.K., Lakhani, K.H., Yates, T.J., Frost, A.J., Plant, R.A. 1993. Insecticide drift from ground-based, hydraulic spraying of peas and brussels sprouts - bioassays for determining buffer zones. Agri. Ecosystem and Environ., 43: 93-108.

Davis, J.C. 1975. The exchange of oxygen at the gills of fish in response to oxygen availability. In: Chemistry and Physics of Aqueous Gas Solutions (ed.: Adams WA). Electrochemical Society, Princeton, N.J., pp. 293.

De Mel Gwjlmvtm, Pathiratne, A. 2005. Toxicity assessment of insecticides commonly used in rice pest management to the fry of common carp, Cyprinus carpio, a food fish culturable in rice fields. J. Appl. Ichthyol., 21: 146-150.

Finney, D.J. 1971. "probit Analysis." (3rd Edition), Cambridge University Press, London, 330.

Fujio, Y., Kaneko, S. 1980. "Differentiation of Lactate Dehydrogenase Isozymes in fish." Tohoku J. Agri. Res., 31: 61-73.

Gordon, M.R., McLeay, D.J. 1977. Sealedjar bioassays for pulp mill effluent toxicity: Effects of fish species and temperature. J. Fish Res. Board Canada, 34: 1389-1396.

Gornall, A.G., Bardawill, C.J., David, M.M. 1949. Determination of total serum proteins by means of biuret reaction. $J$. Biol. Chem., 177: 551-556.

Govindan, V.S., Jacob, L., Devika, R. 1994. Toxicity and metabolic changes in Gambusia affinis exposed to Phosphamidon. J. Ecotoxicol. Env. Monit., 4: 1-6.

Gupta, P.K. 1984. Studies on acute toxicity of some insecticides to a freshwater teleost Lebestes reticulatus (Peters). Acta Hydrochimica et Hydrobiologica, 12: 629 .

Honarpajouh, K. 2003. Study and Identification of OP pesticides residues (Azinphosmethyl and Diazinon) in the Mahabad and Siminerood Rivers, M. Sc Thesis, Tehran University of Medical Science, Tehran, Iran, pp. 95.

Jeba kumar, S.R.D., Kumaraguru, A.K., Jayaraman. J. 1993. Accumulation and dissipation of phosphomidon in the tissues of freshwater fish Oreochromis mossambicus. Comp. Physiol. Ecol., 18: 12-17.

Jee, L.H., Masroor, F., Kang, J.Ch. 2005. Responses of cypermethrin-induced stress in haematological parameters of Korean rockfish, Sebastes schlegeli (Hilgendorf). Aquaculture Res., 36: 898-905.

John, P.J. 2007. Alteration of certain blood parameters of fresh water teleost Mistus vittatus after chronic exposure to metasystox and sevin. Fish Physiol. Biochem., 33: 15-20.

Jones, D.R., Randall, D.J.R., Jarman, G.M. 1970. A graphical analysis of oxygen transfer in fish. Respiratory Physiol., 10: 285-298.

Joyce shoba Rani, V., Janaiah, C. 1991. Ammonia metabolism in freshwater teleost clarias batrachus(Linn) on 
exposure to trichlorofon. Bull. Environ. Contam. Toxicol., 46: 731737.

Jyothirmayee, S., Jane theophillus, Padma Balaravi, Narender Reddy, T., Reddy, P.U.M. 2006. "Endosulfan induced changes in esterases of Anabas testudineus and Clarias batrachus". Indian Journal of comparative animal physiol., 24: 95-99.

Jyothirmayee, S., Padma Balaravi., Jane theophillus, Narender Reddy, T., Reddy, P.U.M. 2005. "Chromium induced changes in electrophoretic patterns of esterases in freshwater fishes Clarias batrachus and Anabas testudineus". J. Aqua. Biol., 20: 130134.

Kabeer, A.I., Begum, M.D., Sivaiah, S., Ramana Rao, K.V. 1984. Sub-lethal toxicity of malathian on the proteases and free amino acid composition in the liver of teleost, Tilapa mossambica(Peters). Toxicol. Lett., 20: 59-62.

Kemp, A., Kits, V.A.J.M. 1975. A colorimetric micromethod for the determination of glygogen in tissues. J. Biochem., 56: 646-648.

Macek, K.J., Hutchinson, C., Cope, O.B. 1969. The effects of temperature on the susceptibility of bluegills and rainbow trout to selected pesticides. Bulletin of Environmental Contamination and Toxicology, 4: 174-183.

Macek, K.J., Hutchinson, C., Cope, O.B., 196. The effects of temperature on the susceptibility of bluegills and rainbow trout to selected pesticides. Bulletin of Environmental Contamination and Toxicology, 4: 174-183.

Markert, C.L., Moller, F. 1959. "Multiple forms of enzymes tissue, ontogenetic and species specific pattern." Proc. Nat. Acad. Sci., 45: 753- 763.
Masopust, J. 2000. Clinical Biochemistry (in Czech). Karolinum, Prague. 832 pp.

Monteiro, D.A., Alves de Almeida, J., Rantin, F.T., Kalinin, A.L. 2006. Oxidative stress biomarkers in the freshwater characid fish, Brycon cephalus, exposed to organophosphate insecticide Folisuper 600 (methyl parathion). Comparative Biochem. Physiol., Part C 143: 141-149.

Muirhead-Thomson, R.C. 1971. Pesticide and freshwater fauna. Academic Press Inc., London, pp 248.

Mukhopadhyay, P.K., Dehadrai. 1980. Biochemical changes in the air breathing eat fish Clarias batrachus(Linn) exposed to malathion. Environ. Pollut. Ser. A., 22: 149-158.

Nagabhushanam, R., Kedarkar, M.S., Sarojini, R. 1983. Text book of animal physiology, Oxford and IBM publishing co., New Delhi.

Natarajan, G.M. 1989. Changes in the carbohydrate metabolism during acute and chronic exposure of air breathing fish Channa straistus to xydemeton methyl(Metasystax), Comp. Physiol. Ecol., 14: 181-184.

Parithabhanu, A., Subramanian, M.A. 2006. Impact of mercuric chloride on the biochemical composition of blood of Clarius batrachus (Linn), J. Curr. Sci., 9(1): 77- 80.

Philip, G.H., Reddy, P.M., Sridevi, G. 1995. Cypermethrin-induced in vivo alterations inthe carbohydrate metabolism of freshwater fish, Labeo rohita. Ecotoxicol. Environ. Safety, Vol. 31, No. 2, (July 1995), pp. 173178, ISSN 0147-651

Polat, H., Erkoc, F.U., Viran, R., Kocak, O. 2002. Investigation of acute toxicity of beta-cypermethrin on guppies Poecilia reticulata. Chemosphere, 49: 39-44.

Roe, J.H. 1955. The determination of sugar in blood and spinal fluid with 
anthroma reagent, J. Biol. Chem., 212: 335-343.

Schimmel, S.C., Patrick, Jr. J.M., Forester, J. 1976. Heptachlor-toxicity to and uptake by several estuarine organisms. Journal of Toxicological and Environmental Health, 1: 955-965.

Shahpour, Dalaky of Bushehr province in 2004- 2005 years. Iranian South Medical Journals, 10(1): 54- 60.

Shayeghi, M., Darabi, H., Abtahi, H., Sadeghi, M., Pakbaz, F., Golestaneh, S.R. 2007. Assessment of persistence and residue of diazinon and malathion in three Rivers.

Shukla, M. 1995. Toxicological assessment of some common pollutants on a freshwater fish.Ph.D. Thesis, University of Gorakhpur, Gorakhpur, India.

Siang, H.Y., Yee, L.M., Seng, C.T. 2007. Acute toxicity of organochlorine insecticide endosulfan and its effect on behavior and some hematological parameters of Asian Swamp eel (Monopterus albus, Zuiew). Pesticide Biochem. Physiol., 89: 46-53.

Simon, L.M., Nemcsok, J., Boross, L. 1983. Studies on the effect of paraquat on glycogen mobilization in liver of common carp (Cyprinus carpio L.). Comparatve Biochem. Physiol., 75C: 167-169.

Singh, B.B., Narain, A.S. 1982. Acute toxicity of thiodon to catfish Heteropneustes fossilis. Bull. Environ. Contamination and Toxicol., 28: 122127.

Singh, R.N., Pandey, R.K, Singh, N.N., Das, V.K. 2009. Acute toxicity and behavioral responses of common carp Cyprinus carpio(Linn) to an organophosphate(Dimethoate). WJZ, 4: 70-75.

Singh, R.N. 2013. Acute Toxicity of an Organophosphate, Diethoate to an air breathing fish, Colisa fasciatus (Bl. \& Schn.), Indian J. Sci. Res., 4(1): 97100.

Singh, R.N., Pandey, R.K, Singh, N.N., Das, V.K. 2009. World J. Zool., 4(2): 7075.

Singh, R.N. 2012. Histopathological alterations in the kidney of Cyprinus carpio after exposure to Dimethoate (30\%). Indian J. Sci. Res., 3: 127-131.

Singh, R.N. 2013. Effects of Dimethoate (30\%), an organophosphate pesticide on liver of common carp, Cyprinus carpio. J. Environ. Biol., 34: 657-661.

Spalding, R.F., Exner, M.E., Snow, D.D., Cassada, D.A., Burbach, M.E., Monson, S.J. 2003. Herbicides in ground water beneath Nebraska's management systems evaluation area, Journal of Environmental Quality, Vol. 32, No. 1, (January 2003), pp. 9298, ISSN 0047-2452

Srinivas, Md., Rafi,. G., Prasad, T.A.V., Reddy, D.C. 1991. Effect of thermal acclimation on the lipid metabolism in a freshwater field crab, Ozaitelphusa senex senex (Fabricius). J. Ecolbiol., 3: 134-147.

Svobodova, Z., Pravda, D., Palackova, J. 1991. Unified methods of haematological examination of fish. Research Institute of Fish Culture and Hydrobiology, Vodnany, Methods No. 20 , pp. 31.

Sweilum, M.A. 2006. Effect of sublethal toxicity of some pesticides on growth parameters, haematological properties and total production of Nile tilapia (Oreochromois niloticus L.) and water quality of ponds. Aquaculture Res., 37: 1079.

Talebi, K. 1998. Diazinon Residues in the Basis of Anzali Lagoon, Iran. Bulletin Environmental

Contamination

Toxicol., 61: 477-483. 
Tarahi Tabrizi, S. 2001. Study of pesticide residues (diazinon, malathion, metasytoux) in the Tabriz Nahand River, M.Sc. Thesis, Tehran University of Medical Science, Tehran, Iran, 1-88.

Under, N., Oruc, E.O., Sevgiler, Y., Sahin, N., Durmaz, H., Usta, D. 2006. Effect of diazionon on acetyl cholinesterase activity and lipid per oxidation in the brain of Oreochromis niloticus. Environmental Toxicol. Pharmacol., 21: 241-245.

Velisek, J., Dobsikova, R., Svobodova, Z., Modra, H., Luskova, V. 2006b. Effect of deltamethrin on the biochemical profile of common carp (Cyprinus carpio L.). Bulletin of Environmental Contamination and Toxicology, Vol. 76, No. 6, (June 2006), pp. 992-998, ISSN 0007-4861

Velisek, J., Wlasow, T., Gomulka, P., Svobodova, Z., Dobsikova, R., Novotny, L., Dudzik, M. 2006a. Effects of cypermethrin on rainbow trout (Oncorhynchus mykiss). Veterinarni Medicina, Vol. 51, No. 10, (October 2006), pp. 469-476, ISSN 0375-8427

Velisek. J.T., Wlasow, P., Gomulka, Z.,
Svobodova, R., Dobsikova, L., Novotny, M., Dudzi. 2006. Effects of cypermethrin on rainbow trout (Oncorhynchus mykiss), Veterinarni Medicina, 51(10): 469-476.

Vittozzi, L., Angelis, G.D. 1991. A critical review of comparative acute toxicity data on freshwater fish. Aquatic Toxicol., 19: 167-204.

Vryzas, Z., Vassiliou, G., Alexoudis, C., Papadopoulou- Mourkidou, E. 2009. Spatial and temporal distribution of pesticide residues in surface waters in northeasterm Greece. Water Res., 43: 1-10.

Wedemeyer, G.A., Mayer, F.P., Smith, L. 1976. Environmental stress and fish diseases. Diseases of fishes, Book 5 (eds.: Srieszko SF, Axelrod HR). T.H.F. Publication, Neptune, pp. 192.

Werimo, K., Bergweff, A.A., Seinen, W. 2009. Residue levels of organochlorines and organophosphates in water, fish and sediments from Lake Victoria- Kenyan portion. Aquatic Ecosystem Health \& Management, 12: 337-34.

Yemm, E.W., Cocking, E.C. 1957. The determination of amino acid in the ninhydrin, Analyst, 80: 209-213.

\section{How to cite this article:}

Mohammad Illiyas Hussain, Baidyanath Kumar and Mumtaz Ahmad. 2016. Effect of Organophosphate Insecticide, Dimethoate on Physiology of Common carp, Catla catla (Hamilton) and Labeo rohita.Int.J.Curr.Microbiol.App.Sci. 5(5): 322-341. doi: http://dx.doi.org/10.20546/ijcmas.2016.505.034 